\title{
EFFICIENCY OF INTRODUCTION OF ACC-UTILIZING RHIZOBACTERIA IN SOYBEAN AGROCENOSES IN THE OREL REGION
}

\section{Yu.V. KUZMICHEVA, I.L. TYCHINSKAYA, S.N. PETROVA, N.V. PARAKHIN}

Orel State Agrarian University, 69, ul. Generala Rodina, Orel, 302019 Russia, e-mail juliemons@yandex.ru Received March 30, 2015

\section{Abstract}

Resource-saving technologies contribute to the reproduction of the soil fertility and increase sustainability of agrocenoses. Legumes are most relevant to the modern requirements for formation of ecological balance. They form a multicomponent symbiosis with various groups of useful soil microflora, which not only improves soil properties and increase the yield and its quality, but also makes them a valuable precursor in the rotation. In this regard, promising search and practical use of new microorganisms with multifunctional properties that will improve the economic efficiency of legume cropcultivation. Of particular interest is the use of ACC-utilizing bacteria having a versatile anti-stress effect on plants. We have carried out a study on the impact of the introduction of promising strains ACC utilizing rhizobacteria (Pseudomonas oryzihabitans Ep4 and Variovorax paradoxus 3P-4) and nodule bacteria (Bradyrhizobium japonicum 634b) on efficiency of cultivation of the northern soybean ecotype Svapa in Orel Region depending on mineral nutrition (NPK $100 \%$ and NPK $70 \%$ ). The strain of nodule bacteria was used for inoculation of seeds in the amount of $200 \mathrm{~g}$ per hectare seed rate. Strains of associative ACC utilizing microorganisms were added to the rows in the seedling stage (10\% solution). NPK was applied to the soil before planting in the form of fertilizer mixture with the percentage of mineral nutrients 10:26:26. Biochemical assessment of the quality of soybean was performed in the laboratory conditions. In forming symbioses with introduced microflora the soybean agrocenoses were more environmentally adaptable, which was reflected in increasing the productivity in drought years by $35-98 \%$. The positive effect of the bacteria was evident in increasing the grain protein content by $34 \%$. Getting a high yield and high yield quality of the studied soybean variety due to formation of effective plant-microbe system leaded to the increase of total protein up to $1.05-1.30 \mathrm{t} / \mathrm{ha}$. The introduction of microorganisms was the most effective at lowering the dose of mineral fertilizers by $30 \%$. It was found that the use of rhizobacteria Pseudomonas oryzihabitans together with nodule bacteria ensured maximum economic benefit and allowed to obtain cheaper and high-quality protein with high profitability. This will reduce the costs associated with the application of mineral fertilizers without crop losses.

Keywords: soybean, agrocenosis, ACC-utilizing rhizobacteria, symbiosis, economic efficiency, resource conservation.

The reduction of the productivity of agrocenoses, of crops quality and natural soil fertility as the result of agricultural production intensification requires its ecologization. To ensure food safety of the country and human health, a transition towards resource-saving technologies is required, which contributes to the reproduction of soil fertility and the increase in sustainability of agrocenoses based on the use of environment-forming potential of the latter [1, 2].

Legumes are most relevant to the modern requirements for formation of ecological balance [1, 3-5]. Their unique ability to form a multicomponent symbiosis with various groups of useful soil microflora not only improves soil properties and increases the yield and its quality, but also makes them a valuable precursor in the rotation, thus contributing to solving the problem of the production of vegetable protein at the possibility of reducing resource consumption [4, 6-14].

In this regard, the search and practical use of new microorganisms with 
multifunctional properties is promising which will make it possible to improve the economic efficiency of legume cropcultivation through the implementation of their biological potential. Of particular interest is the use of ACC (1-aminocyclopropane-1-carboxylate) utilizing bacteria with a versatile anti-stress effect on plants. One of the mechanisms of anti-stress effects of these organisms is the suppression of the inhibitory effect of ethylene, intensively produced by macrosymbiont under stress conditions (infections, drought, waterlogging, soil salinization, its pollution of industrial waste, pesticides, heavy metals, etc.) due to the ACC deaminase enzyme [15-17]. The results of numerous laboratory tests prove the phyto-stimulating effect of associated bacteria with the ACC deaminase activity [18-29]. At the same time, there is no information on the effectiveness of such microorganisms in the conditions of agrocenosis.

Our objective was to study the effect of the introduction of promising strains of ACC utilizing rhizobacteria on the effectiveness of cultivation of the northern soybean ecotype under the conditions of Orel Region.

Technique. Laboratory studies were performed at CCU Ecological and agrochemical monitoring of agricultural production and the environment (Orel State Agrarian University), field experiments were conducted at the Integration (research, education and production center, Orel Region, Lavrovo settlement) in 2013-2014.

Soybean Svapa variety plants were grown in breeding crop rotation at the plots of $10 \mathrm{~m}^{2}$ in a 4-fold repetition. A randomized method of test plots placement was used. The experimental plot soil is dark gray, forest, clayey loamy, medium acid ( $\mathrm{pH} 5.0$ ), with intermediate content of humus (3.8\%), increased number of mobile phosphorus $(12.9 \mathrm{mg} / 100 \mathrm{~g})$ and exchangeable potassium $(15.9 \mathrm{mg} / 100 \mathrm{~g})$. Northern soybean ecotype Svapa (selection of the AllRussia Research Institute of Legumes and Groat Crops, Orel Province) was used as the experimental object.

In experiments, the efficacy of the introduction of ACC utilizing bacteria alone and in combination with rhizobia against the background of mineral nutrition of NPK $100 \%$ (dose of fertilizer for the planned harvest of $3 \mathrm{t} / \mathrm{ha}$ ) and NPK $70 \%$ was studied.

The experimental pattern included the following options: 1 - control (background of NPK $100 \%$ and NPK $70 \%$ without inoculation); 2 - background + Bradyrhizobium japonicum 634b; 3 - background + Pseudomonas oryzihabitans Ep4; 4 - background + Variovorax paradoxus 3P-4; 5 - background + Bradyrhizobium japonicum 634b + Pseudomonas oryzihabitans Ep4; 6 - background + Bradyrhizobium japonicum $634 \mathrm{~b}+$ Variovorax paradoxus 3P-4.

Bacteria strains were provided by the All-Russian Research Institute for Agricultural Microbiology (St. Petersburg-Pushkin). The strain of nodule bacteria was used for inoculation of seeds in the amount of $200 \mathrm{~g}$ per hectare seed rate. Strains of associative ACC utilizing microorganisms were added to the rows in the seedling stage (10\% solution). NPK was applied to soil before planting as the fertilizer mixture with the percentage of mineral nutrients of 10:26:26.

Yield assessment of varieties was performed according to stated procedure [30], for biochemical assay of soybean grain quality an Infratec ${ }^{\mathrm{TM}} 1241$ grain analyzer (FOSS, Denmark) was used.

Data were processed by the Statistica computer program.

Results. Meteorological conditions during the study deviated from the long-term average conditions and were accompanied by the uneven distribution of rainfall and temperature fluctuations throughout the soybean growing season. Moisture supply for the crops at critical periods of culture development was insufficient. For example, May decade II accounting for planting soybean 
was characterized by arid conditions $(\mathrm{HTC}=0.2)$. In July, which coincided with budding and flowering, in 2013, unsufficient humidification was noted (HTC $=0.9)$, and in 2014, July was a dry month $($ HTC $=0.3)$. August of 2013 and 2014 when development and ripening of seeds took place was characterized by drought (HTC 0.6 and 0.2 , respectively).
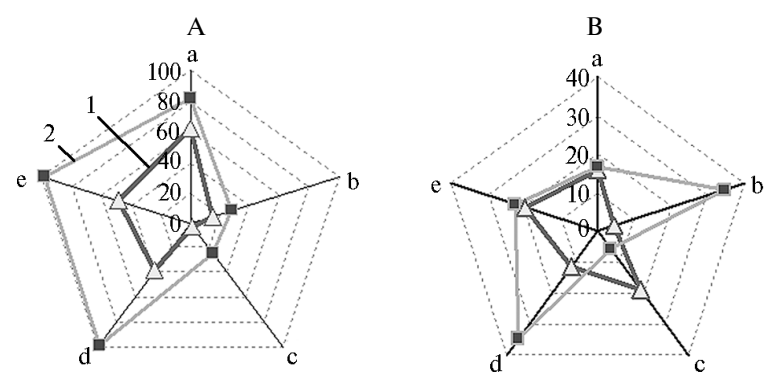

Fig. 1. Relative increase of soybean Svapa productivity in 2013 (A) and 2014 (B) depending on bacterial inoculation and mineral nutrition background: 1 - NPK 100\%, 2 - NPK $70 \%$; a - Bradyrhizobium japonicum 634b, b - Pseudomonas oryzihabitans Ep4, c - Variovorax paradoxus 3P-4, $\mathrm{d}-$ Bradyrhizobium japonicum $634 \mathrm{~b}+$ Pseudomonas oryzihabitans Ep4, e - Bradyrhizobium japonicum 634b + Variovorax paradoxus 3P-4 (Orel Province, Orel Region, Lavrovo settlement). growth-stimulating and anti-stress effect of microorganisms. In 2013, complex bio-stimulating effect of ACC utilizing bacteria and rhizobia made it possible to get an increase of productivity of $81.0-97.8 \%$.

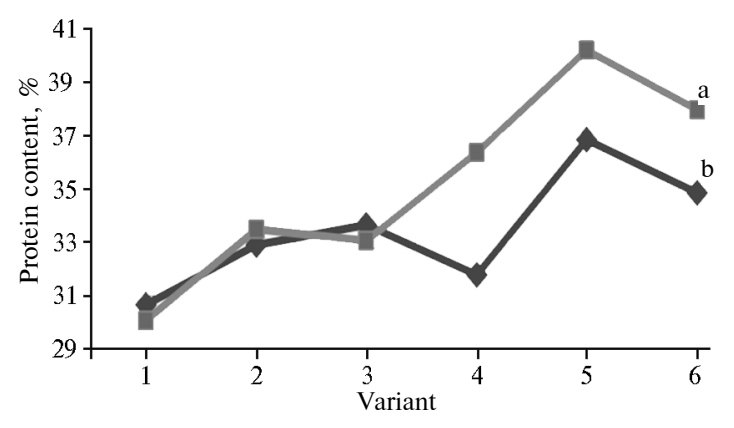

Fig. 2. Protein content in soybean Svapa grains depending on bacterial inoculation against the background of NPK $70 \%$ (a) and $100 \%$ NPK (b): 1 - control, 2 - Bradyrhizobium japonicum 634b, 3 - Pseudomonas oryzihabitans Ep4, 4 - Variovorax paradoxus 3P-4, 5 - Bradyrhizobium japonicum 634b + Pseudomonas oryzihabitans Ep4, 6 Bradyrhizobium japonicum 634b + Variovorax paradoxus 3P-4 (Orel Province, Orel Region, Lavrovo settlement). $\mathrm{LSD}_{05}=1.95(\mathrm{NPK} 100 \%) ; \mathrm{LSD}_{05}=2.11(\mathrm{NPK} 70 \%)$.
In forming symbioses with introduced microflora, the soybean Svapa agrocenosis showed greater environmental adaptability compared with control (Fig. 1). The protective effect of microorganisms was most apparent at lowering the dose of mineral fertilizers by $30 \%$.

Thus, colonization of soybean roots with Pseudomonas alone and in combination with rhizobia in the dry year of 2014 helped to increase the agrocenoses productivity by $34.6 \%$ due to the nas in combination with rhizobia (superior to the option of rhizobia monoinoculation by $20.0 \%$ ). We believe that this positive effect is due to an increase in soybean adaptation to unfavorable agro-climatic factors by reducing the ethylene stress phytohormone biosynthesis by ACC utilizing bacteria and improving the efficiency of rhizobium-legume symbiosis $[18,29]$ with the improvement of water and mineral nutrition of plants.

In turn, formation of high and quality yield in the studied soybean variety through effective plant-microbe systems helped to increase the amount of protein per area unit which reached 1.05-1.30 t/ha depending on mineral nutri- 
tion of plants (Table 1). Maximizing of the Svapa plants protein productivity which exceeded the option of rhizobia monoinoculation by $35.4 \%$ was observed against the background of NPK $70 \%$ with complex introduction of ACC utilizing Pseudomonas and nodule bacteria.

1. Protein yield (t/ha) with soybean Svapa crop depending on the conditions of mineral nutrition and bacterial inoculation (Orel Province, Orel Region, Lavrovo settlement, 2013-2014)

\begin{tabular}{l|cc}
\hline \multicolumn{1}{c|}{ Variant } & NPK 100\% & NPK 70 \% \\
\hline Control & 0.70 & 0.59 \\
Bradyrhizobium japonicum 634b & $1.03^{*}$ & $0.96^{*}$ \\
Pseudomonas oryzihabitans Ep4 & 0.83 & $0.85^{*}$ \\
Variovorax paradoxus 3P-4 & 0.80 & $0.81^{*}$ \\
Bradyrhizobium japonicum 634b + Pseudomonas oryzihabitans Ep4 & $1.04^{*}$ & $1.30^{*}$ \\
Bradyrhizobium japonicum 634b + Variovorax 3P-4 & $1.05^{*}$ & $1.17^{*}$ \\
$\quad$ LSD & 0.15 & 0.16 \\
* Significantly different from controls. & & \\
\hline
\end{tabular}

2. Economic efficiency of soybean Svapa variety cultivation depending on the conditions of mineral nutrition and bacterial inoculation (Orel Province, Orel Province, Lavrovo settlement, 2013-2014)

\begin{tabular}{|c|c|c|c|c|}
\hline Variant & $\begin{array}{l}\text { Production cost, } \\
\text { thousand ru- } \\
\text { bles/ha }\end{array}$ & $\begin{array}{l}\text { Net cost per } 1 \text { ton } \\
\text { of grain, thousand } \\
\text { rubles }\end{array}$ & $\begin{array}{l}\text { Net income, } \\
\text { thousand ru- } \\
\text { bles/ha }\end{array}$ & $\begin{array}{l}\text { Profitability, } \\
\%\end{array}$ \\
\hline \multicolumn{5}{|c|}{ N P K $100 \%$} \\
\hline Control & 14.16 & 6.24 & 20.14 & 142.1 \\
\hline Bradyrhizobium japonicum 634b & 14.59 & $4.68^{*}$ & $32.46^{*}$ & $222.5^{*}$ \\
\hline Pseudomonas oryzihabitans Ep4 & 14.99 & 6.05 & 22.45 & 149.7 \\
\hline Variovorax paradoxus $3 \mathrm{P}-4$ & 15.01 & 5.95 & 23.04 & 153.6 \\
\hline \multicolumn{5}{|l|}{ Bradyrhizobium japonicum } \\
\hline 634b + Pseudomonas oryzihabitans Ep4 & 15.33 & $5.44^{*}$ & $27.22^{*}$ & $177.6^{*}$ \\
\hline $\begin{array}{l}\text { Bradyrhizobium japonicum } 634 \mathrm{~b}+\text { Va- } \\
\text { riovorax paradoxus } 3 \mathrm{P}-4\end{array}$ & 15.36 & $5.09^{*}$ & $30.19^{*}$ & $196.5^{*}$ \\
\hline \multicolumn{5}{|c|}{ N P K $70 \%$} \\
\hline Control & 13.80 & 7.04 & 15.85 & 114.9 \\
\hline Bradyrhizobium japonicum 634b & 14.23 & $4.94^{*}$ & $29.22^{*}$ & $205.3^{*}$ \\
\hline Pseudomonas oryzihabitans Ep4 & 14.69 & $5.72 *$ & $24.11^{*}$ & $164.1^{*}$ \\
\hline Variovorax paradoxus $3 \mathrm{P}-4$ & 14.63 & $6.53^{*}$ & $19.22^{*}$ & $131.3^{*}$ \\
\hline \multicolumn{5}{|l|}{ Bradyrhizobium japonicum } \\
\hline $634 \mathrm{~b}+$ Pseudomonas oryzihabitans Ep4 & 15.09 & $4.69^{*}$ & $33.46^{*}$ & $221.7^{*}$ \\
\hline $\begin{array}{l}\text { Bradyrhizobium japonicum } 634 \mathrm{~b}+\text { Va- } \\
\text { riovorax paradoxus } 3 \mathrm{P}-4\end{array}$ & 15.07 & $4.89^{*}$ & $31.39^{*}$ & $208.3^{*}$ \\
\hline
\end{tabular}

Our economic analysis demonstrated that, despite a slight increase in production cost, introduction of symbiotic microorganisms in soybean variety Svapa agrocenosis provided positive economic effect. Morover, with less fertilizer (NPK $70 \%$ ), studied agricultural practices have proven to be most effective economically (Table 2).

The maximum economic benefit was reached by the option of integrated use of Pseudomonas and rhizobia, which provided soybean at a lower cost (1.6 times lower compared to control). This, in turn, enables the cost-effective production of a cheaper quality protein while reducing the cost related to the application of mineral fertilizers, in the amount of 2.86 thousand rubles/ha.

Thus, the introduction of promising ACC utilizing bacteria strains enhanced the effectiveness of soybean Svapa cultivation in Orel region. It has been shown that the plants of this genotype in a triple symbiosis can use the nutrients of the soil and the air more efficiently, due to growth-stimulating and protective functions of ACC utilizing nitrogen-fixing microorganisms, which makes it possible to increase their resistance to stress and productivity. The use of Pseudomonas rhizobacteria in combination with rhizobia provided maximum economic benefit making it possible to get a cheaper quality protein with high 
production profitability and reduction of resource consumption by improving the environmental sustainability of agrocenoses.

\section{REFERENCES}

1. Z hu c he n k o A.A. Vestnik OrelGAU, 2009, 18(3): 8-12.

2. S y t n ik o v D.M. Biotekhnologiya, 2012, 5(4): 34-45.

3. D a vyde n k o O.G., G o le nk o D.V. Soya dlya umerennogo klimata [Soybean production under temperate climate conditions]. Minsk, 2004.

4. P a r a k h i n N.V., P e t rov a S.N. Sel'skokhozyaistvennye aspekty simbioticheskoi azotfiksatsii [Agricultural aspects of symbiotic nitrogen fixation]. Moscow, 2006.

5. Z ot i k o v V.I., N a u m in a T.S. Vestnik OrelGAU, 2007, 3: 11-14.

6. Vance C.P., Spaink H.P., Kondorosi A., Hooykaas P.J.J. Legume symbiotic nitrogen fixation: agronomic aspects. In: The Rhizobiaceae. Dordrecht, 1998: 509-530.

7. Ku z mi c h e va Yu.V., P e t rova S.N. Zernobobovye i krupyanye kul'tury, 2013, 8(4): 43-48.

8. Tikhonovich I.A., Provorov N.A. Simbiozy rastenii i mikroorganizmov: molekulyarnaya genetika agrosistem budushchego [Plant-microbe symbioses: molecular genetics of future agrosystems]. St. Petersburg, 2009.

9. Borisov A.Yu., Shtark O.Yu., Kazakov A.E., Naumkina T.S., Chebotar' V.K. Materialy Vserossiiskoi nauchno-prakticheskoi konferentsii «Puti povysheniya ustoichivosti sel'skokhozyaistvennogo proizvodstva $v$ sovremennykh usloviyakh» [Proc. All-Russian Conf. «Ways to improve the sustainability of agricultural production in modern conditions»]. Orel, 2005: 325-348.

10. Kuz mi cheva Yu.V., P a rakhin N.V. Rossiiskaya sel'skokhozyaistvennaya nauka, 2015, 1-2: 31-33.

11. K u z m i c he va Yu.V., P a ra k h i n N.V. Vestnik OrelGAU, 2014, 49(4): 3-6.

12. Parakhin N.V., Kuzmicheva Yu.V., Petrova S.N., Botuz N.I., Tychins k a y a I.L. Vestnik OrelGAU, 2014, 47(2): 3-6.

13. Parakhin N.V., K u z mi che va Yu.V. Izvestiya Orenburgskogo gosudarstvennogo agrarnogo universiteta, 2012, 38(6): 66-68.

14. Parakhin N.V., Petrova S.N., Kuzmicheva Yu.V. Izvestiya Nizhnevolzhskogo agrouniversitetskogo kompleksa, 2012, 28(4): 85-89.

15. B e li m o v A.A., S a fro n o v a V.I. Sel'skokhozyaistvennaya biologiya [Agricultural Biology], 2011, 3: 23-28 (http://www.agrobiology.ru/3-2011safronova-eng.html).

16. Belimov A.A., Hontzeas N., S a fronova V.I., Demchinskaya S.V., Pi luzza G., B ullitt a S., G lick B.R. Cadmium-tolerant plant growth-promoting bacteria associated with the roots of Indian mustard (Brassica juncea L. Czern.). Soil Biol. Biochem, 2005, 37: 241-250 (doi: 10.1016/j.soilbio.2004.07.033).

17. Czarny J.C., Grichko V.P., Glick B.R. Genetic modulation of ethylene biosynthesis and signaling in plants. Biotech. Adv., 2006, 24: 410-419 (doi: 10.1016/j.biotechadv.2006.01.003).

18. B e li mov A.A. Vzaimodeistvie assotsiativnykh bakterii $i$ rastenii $v$ zavisimosti ot bioticheskikh i abioticheskikh faktorov. Avtoreferat doktorskoi dissertatsii [An interaction of associative bacteria and plants depending on biotic and abiotic factors. DSci Thesis]. St. Petersburg, 2008.

19. Cheng Z., Park E., Glick B.R. 1-Aminocyclopropane-1-carboxylate deaminase from Pseudomonas putida UW4 facilitates the growth of canola in the presence of salt. Canadian. $\boldsymbol{J}$. Microbiol., 2007, 53: 912-918.

20. G li ck B.R. Phytoremediation: synergistic use of plants and bacteria to clean up the environment. Biotech. Adv., 2003, 21: 383-393 (doi: 10.1016/S0734-9750(03)00055-7).

21. B u rd G.I., Dix o n D.G., Gli ck B.R. A plant growth promoting bacterium that decreases nickel toxicity in seedlings. Appl. Environ. Microbiol., 1998, 64: 3663-3668.

22. Holguin G., Glick B.R. Transformation of Azospirillum brasilense Cd with an ACC deaminase gene from Enterobacter cloacae UW4 fused to the Tetr gene promoter improves its fitness and plant growth promoting ability. Microbial Ecology, 2003, 4: 122-133.

23. B e li mov A.A., D odd I.C., S a fro nova V.I., D avies W.J. ACC deaminase-containing rhizobacteria improve vegetative development and yield of potato plants grown under water-limited conditions. Aspects of Applied Biology, 2009, 98: 163-169.

24. S a r a v a a ku ma r D., S a m i y a p p a n R. ACC deaminase from Pseudomonas fluorescens mediated saline in groundnut (Arachis hypogea) plants. J. Appl. Microbiol., 2007, 102: 12831292 (doi: 10.1111/j.1365-2672.2006.03179.x).

25. Grichko V.P., G li ck B.R. Amelioration of flooding stress by ACC deaminase-containing plant growth-promoting bacteria. Plant Physiol. Biochem., 2001, 39: 11-17.

26. Mayak S., Tirosh T., Glick B.R. Plant growth-promotion bacteria that confer resis- 
tance to water stress in tomatoes and peppers. Plant Sci., 2004, 166: 525-530.

27. S afronova V.I., S tep anok V.V., Engqvist G.L., A le k s e y ev Y.V., B e 1 i mov A.A. Root-associated bacteria containing 1-aminocyclopropane-1-carboxylate deaminase improve growth and nutrient uptake by pea genotypes cultivated in cadmium supplemented soil. Biol. Fertil. Soils, 2006, 42: 267-272 (doi: 10.1007/s00374-005-0024-y).

28. Beli mov A.A., Dodd I.C., Hontzeas N., Theobald J.C., S afronova V.I., $\mathrm{D}$ a vi e s W.J. Rhizosphere bacteria containing ACC deaminase increase yield of plants grown in drying soil via both local and systemic hormone signalling. New Phytologist, 2009, 181: 413423 (doi: 10.1111/j.1469-8137.2008.02657.x).

29. Gui n e 1 F.C., G e il R.D. A model for the development of the rhizobial and arbuscular mycorrhizal symbioses in legumes and its use to understand the roles of ethylene in the establishment of these two symbioses. Can. J. Bot., 2002, 80: 695-720 (doi: 10.1139/b02-066).

30. Metodika gosudarstvennogo sortoispytaniya sel'skokhozyaistvennykh kul'tur. Obshchaya chast' [Methods of state crop variety trials. Issue 1]. Moscow, 1971. Vypusk 1. 